\title{
Contribution to the mite (Acari) fauna of the Korean Peninsula
}

\author{
Jenö Kontschán ${ }^{1,2, *}$, Sun Jae Park ${ }^{3}$, Jae Won Lim³ ${ }^{3}$ Jeong Mi Hwang ${ }^{4}$ and Hong Yul Seo ${ }^{3}$ \\ ${ }^{1}$ Plant Protection Institute, Centre for Agricultural Research, Hungarian Academy of Sciences, H-1525 Budapest, \\ P.O. Box 102, Hungary \\ ${ }^{2}$ Department of Zoology and Animal Ecology, Szent István University, Gödöllö, Páter Károly str. 1, H-2100, Hungary \\ ${ }^{3}$ Animal Research Division, National Institute of Biological Resources, Gyoungseo-dong, Seo-gu, Inchoen 404-708, Korea \\ ${ }^{4}$ Korean Entomological Institute, Korea University, Anam-dong, Seongbuk-gu, Seoul 136-701, Korea \\ *Correspondent: kontschan.jeno@agrar.mta.hu
}

\begin{abstract}
32 mite species are listed from the Korean Peninsula. One species belongs to the order Prostigmata, family Cryptognathidae, the order Mesostigmata has 20 species and the order Oribatida contains 11 species. Four species from the listed 32 are new for the fauna of the Korean Peninsula, one species belongs to the order Prostigmata (Favognathus maritimus (Shiba, 1969)) and three new species are Oribatida [Camisia biurus (Koch, 1839), Camisia biverrucata (Koch, 1839), Camisia horrida (Hermann, 1804)]. The 28 of the found species are collected in the Democratic People's Republic of Korea; the others were collected in the area of Republic of Korea. Illustrations and short descriptions about the newly found and rarely collected species are given.
\end{abstract}

Keywords: Acari, Mesostigmata, Korean Peninsula, Oribatida, Prostigmata

(C) 2014 National Institute of Biological Resources

DOI: 10.12651/JSR.2014.3.1.063

\section{INTRODUCTION}

The Soil Zoology Collection of the Hungarian Natural History Museum is rich on the unsorted soil samples collected in the both countries of the Korean Peninsula. But more than 200 soil samples are housed in this collection, up to now only few papers are presented for the results of these samples.

Sándor Mahunka, the noted Hungarian mite researcher studied the collected soil samples and he presented only four papers about the mites. Mahunka (1971) presented his new results about the Tarsonemid mites of the samples collected in Democratic People's Republic of Korea, two years later Mahunka (1973) described two new oribatid mites from Democratic People's Republic of Korea, subsequently Mahunka (1980) discovered a new Tarsomonemid species from the newly collected samples and afterwards Mahunka (1982) presented numerous new ptychoid oribatid species from the samples.

The polish Zerconidae specialist, Czeslaw Blaszak, elaborated the Zerconid mites from the collection of the Hungarian Natural History museum and presented two papers about his results (Blaszak, 1976a; 1976b).

More than 30 years later Jenö Kontschán started his work on the mites of these previously collected materials and he and his co-authors presented their results in two papers (Kontschán et al., 2012; 2013) about the Uropodina mites of Korean Peninsula. Currently they described one new species and listed 16 Mesostigmata species new for the Korean Peninsula in their last paper (Kontschán et al., 2014).

\section{Sándor Mahunka's role in the investigation of the Korean mite fauna}

Professor Sándor Mahunka (1937-2012) passed away at the December of 2012. Sándor Mahunka (Fig. 1) was the lead scientist of the Hungarian Natural History Museum; he was the director of the Zoology Department and later the deputy director of the Hungarian Natural History Museum and the head of the Systematic Zoology Research Group of the Hungarian Academy of Sciences. He discovered and described more than 3000 new mite taxa from the all regions of the world, and he intensively studied firstly the Acarid, Tarsonemid mites and later the Oribatids. Asia was one of favorite regions of Sándor Mahun$\mathrm{ka}$, he lead several collection trip into Sri-Lanka, Thailand, Vietnam and Korea as well. He travelled with Henrik Steimann to Democratic People's Republic of Korea in 1970 and collected 38 soil samples in several different areas of North-Korea. As I earlier mentioned, Sándor 


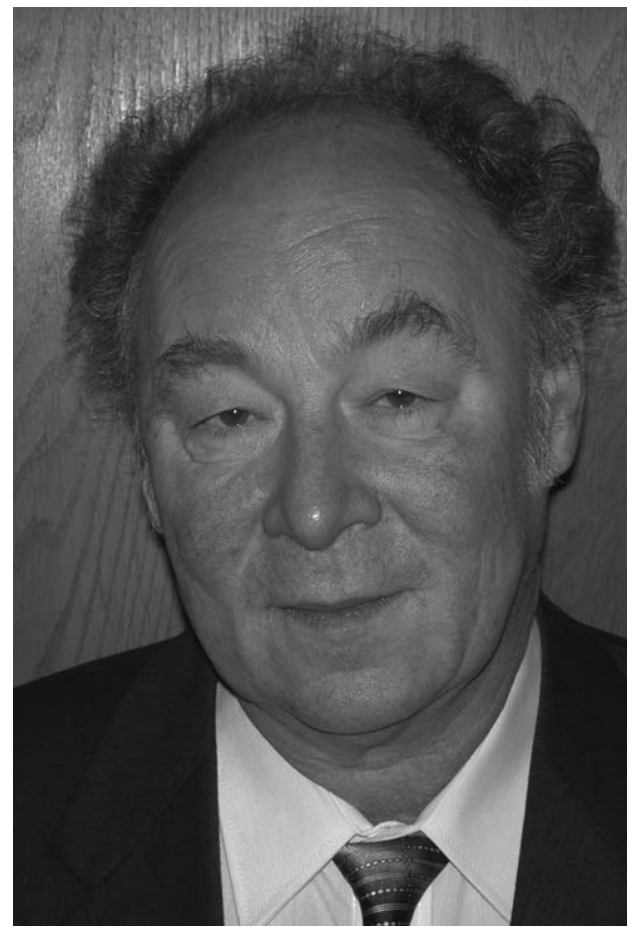

Fig. 1. Sándor Mahunka (1937-2012) (Photo: Csaba Csuzdi).
Mahunka presented four papers about this collection trip accompanied with several new samples collected by other Hungarian Researchers. Sándor Mahunka was one of largest Oribatid specialist of the world; he discovered and described 12 new species from the family Lohmanniidae (Fig. 2) and from the ptychoid Oribatids (Fig. 3) from the area of the Korean Peninsula.

\section{Materials ANd Methods}

Newly collected specimens were found from the collection of the Soil Zoology of Hungarian Natural History Museum (Budapest, Hungary) (HNHM). The specimens were cleared in lactic acid and observed in the deep and half covered slides in scientific microscope or prepared on slide with Kaiser Fluid or lactic acid and gelatin mixture. Illustrations were made with a drawing tube. Scanning micrographs were taken in the Hungarian Natural History Museum, Budapest with a HITACHI SN 2600 scanning electron microscope; specimens investigated were spotter coated by golden-palladium. Measurements are given in micrometers $(\mu \mathrm{m})$, width of idiosoma was taken at the level of coxae IV.
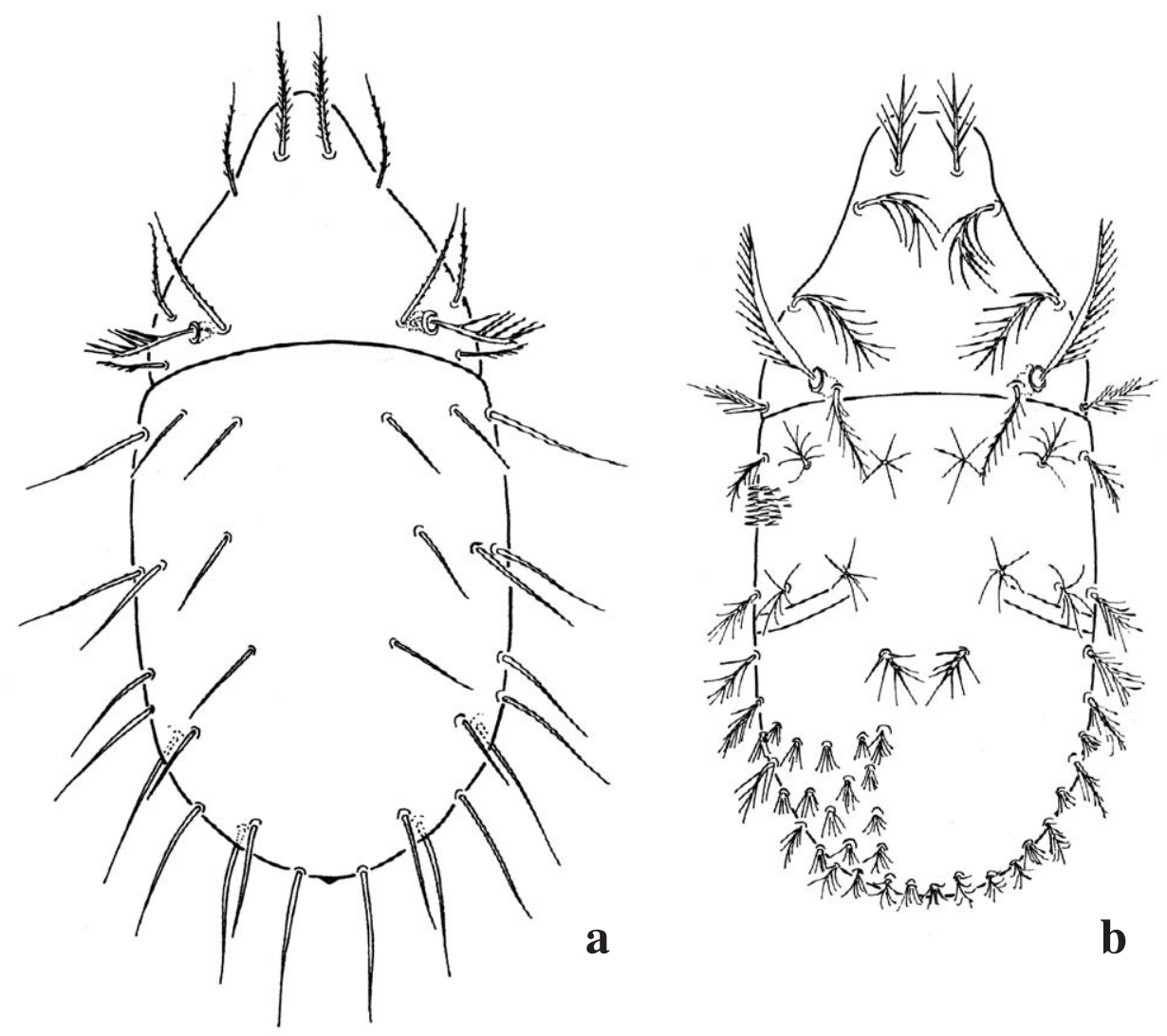

Fig. 2. Sándor Mahunka's Lohmanniids from Korean Peninsula (a. Mixacarus vanhonggui Mahunka, 1973. b. Vepracarus koreanus Mahunka, 1973) (after Mahunka (1973), modified). 


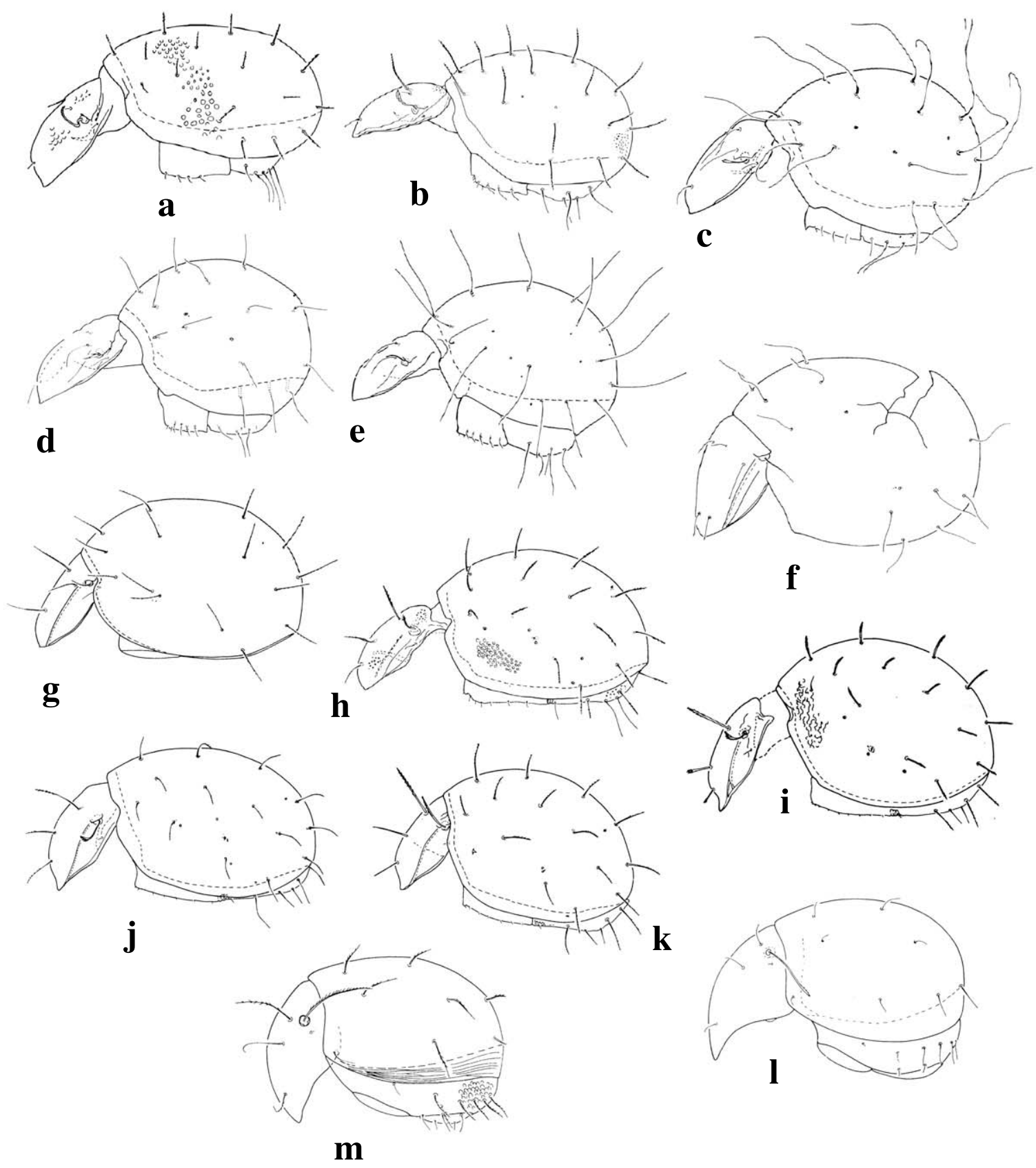

Fig. 3. Sándor Mahunka's ptychoid oribatids from Korean Peninsula (a. Steganacarus trichosus Mahunka, 1981. b. Hoplophthiracarus wittmeri Bayumi \& Mahunka, 1979. c. Phthiracarus dudichi Mahunka, 1981. d. Phthiracarus persicomplex Mahunka, 1981. e. Archiphthiracarus filiferus Mahunka, 1981. f. Oribotritia angusta Mahunka, 1981. g. Oribatritia koreense Mahunka, 1981. h. Euphthiracarus cribrarius (Berlese, 1904). i. Rhysotritia penicillata Mahunka, 1981. j. Rhysotritia rasile Mahunka, 1981. k. Rhysotritia simile Mahunka, 1981. 1. Archoplophora rostralis (Willmann, 1930). m. Dudichoplophora reticulata Mahunka, 1981) (after Mahunka (1981), modified)).

Newly found (publishing here and in Kontschán et al., 2014) and rare species in Korea are illustrated and are given a short description to help to recognize of these species.

The specimens examined are deposited in the Soil Zoology Collection of Hungarian Natural History Museum (Budapest, Hungary) (HNHM) and in the National Insti- tute of Biological Resources, Incheon, Republic of Korea (NIBR).

\section{List of the investigated soil samples}

As197, Democratic People's Republic of Korea, South Phenan Province: Pyongyang, Te-dong gang, steep lake- 
side cliff, 27.V.1970, leg. Mahunka, S. \& Steinmann, H.

As209, Democratic People's Republic of Korea, Prov.

Kangwon: Kumgang, Sam-il out above lakeshore, litter of oak woods, 29.V.1970. leg. Mahunka, S. \& Steinmann, $\mathrm{H}$.

As212, Democratic People's Republic of Korea, Prov. Kangwon: Kumgang san, Man-mul san, from ant nest, 30.V.1970, leg. Mahunka, S. \& Steinmann, H.

As215, One female (NIBR). Democratic People's Republic of Korea, Kangwon Province, Kum-gang san, Guryong waterfall, Pokpo, riverside northern slope, mosses from soil surface and cliff-side, 01.VI.1970, leg. Mahunka, S. \& Steinmann, H.

As224, Democratic People's Republic of Korea, Prov. Kengi: Bagyon waterfall or Pokpo, San-chon tong, about $20 \mathrm{~km}$ SE from Kaesong, margin of stream bed, ant nest under stone, 08.VI.1970, leg. Mahunka, S. \& Steinmann, $\mathrm{H}$.

As229, Democratic People's Republic of Korea, Prov. North Hwanghae, Bagyon san, San-chon tong, about 10 $\mathrm{km}$ from Kaesong, sweet chestnut woods, sod of grass (turf) beyond margin of woods, 08.VI.1970, Mahunka, S. \& Steinmann, H.

As420, Democratic People's Republic of Korea, South Pyongan Prov., Mt. Lyong-ak, $15 \mathrm{~km}$ W of Pyongan, moss sample, collected from a big stone, to be extracted in Szabó-funnel, 09.IX.1980, leg. Forró, L. \& Topál, Gy.

As443, Democratic People's Republic of Korea, Kangwon Prov., Mt. Kumgang, near Hotel Kumgang, five soil traps with, in coniferous forest with rich undergrowth, 29.IX.1979.09, leg. Steinmann, H. \& Vásárhelyi, T.

As446, Democratic People's Republic of Korea, Pyongyang City: Mt. Daesong, $10 \mathrm{~km} \mathrm{NW}$ of Pyongyang, soil sample taken from Pinus forest near Ingo pond to be extracted in Berlese-funnel, 08.VII.1982, leg. Forró, L. \& Ronkay, L.

As450, Democratic People's Republic of Korea, Pyongyang City: Mt. Ryongak, soil sample taken from a mixed forest to be extracted in Berlese-funnel, 12.VII.1982, leg. Forró, L. \& Ronkay, L.

As452, Democratic People's Republic of Korea, North Pyongan Prov., Mt. Myohyang sites litter taken from a mixed forest under Unsam waterfall (Pokpo) to be extracted in Moczarsky-Winkler apparatus, 17.VII.1982, leg. Forró, L. \& Ronkay, L.

As454, Democratic People's Republic of Korea, North Pyongan Prov., Mt. Myohyang sifted litter taken under Ryongyon waterfall (Pokpo) to be extracted in Moczarsky-Winkler apparatus, 15.VII.1982, leg. Forró, L. \& Ronkay, L.

As455, Democratic People's Republic of Korea, North Pyongan Prov., Mt. Myohyang sifted material collected in the mixed forest behind Hotel Myohyang-san to be extracted in Moczarsky-Winkler apparatus, 17.VII.1982, leg. Forró, L. \& Ronkay, L.

As462, Democratic People's Republic of Korea, North Pyongan Prov., Mt. Myohyang soil sample from mixed forest under Hwajangam to be extracted in Berlese-funnel, 19.VII.1980, leg. Forró, L. \& Ronkay, L.

As558, Democratic People's Republic of Korea, North Pyongan Prov., Mt. Myohyang, pathway Sangwon-am, sifted material from the litter of a rocky forest, to be extracted by Moczarsky-Winkler-funnel, 09.X.1987, leg. Korsós, Z. \& Ronkay, L.

As571, Democratic People's Republic of Korea, Ryanggang Province: NW or Samjiyon, $31 \mathrm{~km}$ on Paekdu-san road, Larix vologensis forest (not mixed with Betula pendula) with rather poor underwood, not far from the tree borderline, sifting decayed trunks of Larix volgensis, 28. VI.1988, leg. Merkl, O. \& Szél, Gy.

As574, Democratic People's Republic of Korea, Geumgangsan, pine forest, soil, 11.VII.1988, leg. Merkl, O. \& Szél, Gy.

As665, Democratic People's Republic of Korea, Prov. Jeju, Halla-san National Park, moss and soil samples (four different items) were taken from mosses, detritus, litter and upper layers of soil, 30.X.1993, leg. Peregovits, L. \& Ronkay, L.

As956, Republic of Korea, Gyeongsangnam province, Sancheong-gun, Mt. Jiri, Ogeok valley, $3 \mathrm{~km} \mathrm{NW}$ of Daewon temple, $\mathrm{N}$ branch of Yup-yeong, mixed forest, forest stream, open spring and its outlet, forest edge, 675 $\mathrm{m}, \mathrm{N} 35^{\circ} 22.926^{\prime} \mathrm{E} 127^{\circ} 47.112^{\prime}, 16.09 .2010$, leg. Hye Woo Byeon, László Forró, Tae Woo Kim, Makranczy, Gy. \& Murányi, D.

As957, Republic of Korea, Jeollabuk province, Mujugun, Mt. Deokyu, Baekryeon temple, towards Osujagul cave, Gucheondong stream, surrounding deciduous forest and its side brook, $985 \mathrm{~m}, \mathrm{~N} 35^{\circ} 51.069^{\prime} \mathrm{E} 127^{\circ} 46.169^{\prime}$, 14.09.2010, leg. Hye Woo Byeon, Tae Woo Kim, György Makranczy, Gy. \& Murányi, D.

As961, Republic of Korea, Gyeonggi province, Gapyeong-gun, Mt. Hwaak, Hwaak pass, $2.5 \mathrm{~km} \mathrm{~S}$ of the tunnel, pine forest, $430 \mathrm{~m}, \mathrm{~N} 37^{\circ} 58.465^{\prime} \mathrm{E} 127^{\circ} 31.559^{\prime}$, 11.09.2010, leg. Forró, L., Makranczy, Gy., Murányi D. Sun Jae Park \& Jung Do Yoon.

As963, Republic of Korea, Gangwon province, Injegun, Mt. Seorak Mts, Misi-ryeong pass, beneath the rest area, forest brook, deciduous rocky forest, open grassland and rocks, $745 \mathrm{~m}, \mathrm{~N} 38^{\circ} 12.963^{\prime} \mathrm{E} 128^{\circ} 26.189^{\prime}, 10.09 .2010$, from soil, leg. Murányi, D.

As964, Republic of Korea, Gangwon province, Injegun, Mt. Seorak Mts, Misi-ryeong pass, beneath the rest area, forest brook, deciduous rocky forest, open grassland and rocks, from leaf litter, $745 \mathrm{~m}, \mathrm{~N} 38^{\circ} 12.963^{\prime} \mathrm{E} 128^{\circ}$ $26.189^{\prime}, 10.09 .2010$, leg. Murányi, D. 
Species found

Order Prostigmata

Family Cryptognathidae

\section{Favognathus maritimus (Shiba, 1969) (Fig. 4a, b)}

Material examined. As420, Democratic People's Republic of Korea, South Pyongan Prov.: Mt. Lyong-ak-san, $15 \mathrm{~km} \mathrm{~W}$ of Pyongan, moss sample, collected from a big stone, to be extracted in Szabó-funnel, 09.IX.1980, leg. Forró, L. \& Topál, Gy.

Short description. Small (ca $300 \mu \mathrm{m}$ long) and yellow mites, with pear-like idiosoma. Dorsal part of body covered by reticulate sculptural pattern, hood long and covered by oval pits. Eyes present. Setae on dorsal part of idiosoma long, smooth and needle-like. Prosternal aprom dimpled. Adanal and aggenital setae shorter than dorsal setae, but similar in shape.

Distribution. Japan and Korean Peninsula.

Notes to the species. This is the first record of this species from Korean Peninsula (see Doğan's (2008) world catalog).

\section{Order Mesostigmata}

Family Ascidae

\section{Asca aphidioides (Linnaeus, 1758)}

Material examined. One female (NIBR). As215, One female (NIBR). Democratic People's Republic of Korea, Gangwon-do, Geumgangsan, Guriong waterfall or Pokpo, riverside northern slope, mosses from soil surface and cliff-side, 01.VI.1970, leg. Mahunka, S. \& Steinmann, H.

Distribution. Palearctis.

Notes to the species. This species is recorded only from Republic of Korea (Lee, 1994), but in our previous paper (Kontschán et al., 2014) is mentioned firstly from Democratic People's Republic of Korea.

\section{Asca nubes Ishikawa, 1969}

Material examined. One female (NIBR). Democratic People's Republic of Korea, Gangwon-do, Geumgangsan, Guriong Pokpo (waterfall), riverside northern slope, mosses from soil surface and cliff-side, 01.VI.1970, leg. Mahunka, S. \& Steinmann, H.

Distribution. Japan and Korean Peninsula.

Notes to the species. This species is recorded firstly in our previous paper (Kontschán et al., 2014).

\section{Lasioseius tomokoae Ishikawa, 1969 (Fig. 5a, b)}

Material examined. One female. As454, Democratic People's Republic of Korea, North Pyeonganbuk-do, Mt.

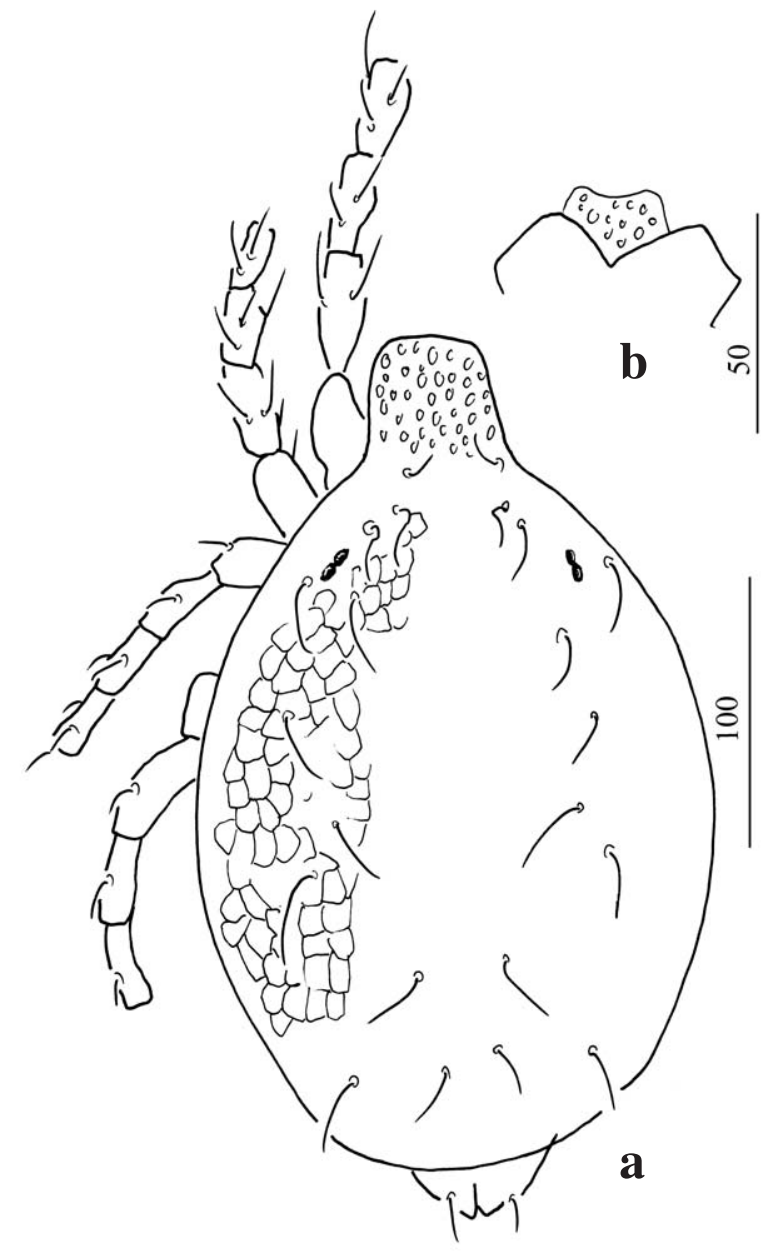

Fig. 4. Favognathus maritimus (Shiba, 1969). a. dorsal view. b. prosternal aprom.

Myohyang sifted litter taken under Ryongyon waterfall to be extracted in Moczarsky-Winkler apparatus, 15.VII. 1982, leg. Forró, L. \& Ronkay, L.

Short description. Idiosoma oval, with yellow colorization. Dorsal shield with reticulate sculptural pattern, dorsal setae long, apically wide and serrate, except one pair needle-like setae on anterior margin of dorsal shield. Setae on ventral idiosoma (on ventrianal shield and sterna shield) smooth and needle-like, except one pair long and robust setae on membranous cuticle near the margin of ventrianal shield.

Distribution. Japan and Korean Peninsula.

Notes to the species. This species is recorded firstly in our previous paper (Kontschán et al., 2014).

Family Eviphididae

Evimirus uropodinus (Berlese, 1903) (Fig. 5c)

Material examined. One female. As229, Democratic 
People's Republic of Korea, North Hwanghaebuk-do: Bagyon san, San-chon tong, about $10 \mathrm{~km}$ from Kaesong sweet chestnut woods, sod of grass (turf) beyond margin of woods, 08.VI.1970, Mahunka, S. \& Steinmann, H. (NIBR).

Short description. Idiosoma circle with pink colorization. Dorsal setae smooth and very short, holodorsal shield present. Sternal shield narrow, genital shield of female triangular, anal shield wider than long. Peritrematal shields wide, stigmata situated at level of anterior margin of coxae IV. Near anal shield short and robust setae situated. Distribution. Europe, Japan and Korean Peninsula. This species has maybe a Palearctic distribution type.

Notes to the species. This species is recorded firstly in our previous paper (Kontschán et al., 2014).

\section{Family Macrochelidae}

\section{Macrocheles glaber (Müller, 1860) (Fig. 5d)}

Material examined. One female. As443, Democratic People's Republic of Korea, Gangwon-do, Mt. Kumgang, near Hotel Geumgang, five soil traps in them, in coniferous forest with rich undergrowth, 29.IX.1979, leg. Steinmann, H. \& Vásárhelyi, T. (NIBR).

Short description. Majority of dorsal setae smooth, except j1 and J5. Ventral shield with fine reticulate sculptural pattern. Setae on ventral idiosoma smooth, Sternal shield with well observed lines and area punctatae posteriores. Ventrianal shield with distinct net-like sculpture. Distribution. Europe, Asia, North-America and Australia. This species occurs presumably in the temperate climatic zones.

Notes to the species. This species is recorded firstly in our previous paper (Kontschán et al., 2014).

\section{Macrocheles punctatus Ishikawa, 1967 (Fig. 5e, f)}

Material examined. Two females. As462, Democratic People's Republic of Korea, North Pyeonganbuk-do, Mt. Myohyang soil sample from mixed forest under Hwajangam to be extracted in Berlese-funnel, 19.VII.1980, leg. Forró, L. \& Ronkay, L.

Short description. Dorsal shield covered by large, irregular pits, dorsal setae marginally pilose, except four pairs in central region, which are smooth and needle-like. Setae j1 very wide and pilose. Sternal shield with some oval pits between setae St3, ventrianal shield covered by irregular and large pits and with three pairs of pilose setae.

Distribution. Japan and Korean Peninsula.

Notes to the species. This species is recorded firstly in our previous paper (Kontschán et al., 2014).
Family Pachylaelapidae

Pachylaelaps ishizuchiensis Ishikawa, 1977 (Fig. 5g)

Material examined. As571, As571, Democratic People's Republic of Korea, Yanggang-do, NW of Samjiyeon, 31 $\mathrm{km}$ on Baekdusan road, Larix vologensis forest (not mixed with Betula pendula) with rather poor underwood, not far from the tree borderline, sifting decayed trunks of Larix volgensis, 28.VI.1988, leg. Merkl, O. \& Szél, Gy.

Short description. Setae on dorsal and ventral parts of idiosoma smooth and needle-like. Sternal shield with reticulate sculptural pattern. Anal shield not fused with genital shield in female. Epistome calypx-shaped with pilose apical margin.

Distribution. Japan and Korean Peninsula.

Notes to the species. This species is recorded firstly in our previous paper (Kontschán et al., 2014).

Family Ologamasidae

\section{Gamasellus humosus Ishikawa, 1969}

Material examined. One female (NIBR). As214. Democratic People's Republic of Korea, Gangwon-do, Geumgangsan, Guriong Pokpo, cliffs near waterfall basin, moss wetted by seeping water in the same site, 01.VI.1970, leg. Mahunka, S. \& Steinmann, H.

Distribution. Japan and Korean Peninsula.

Notes. This species is recorded firstly in our previous paper (Kontschán et al., 2014).

\section{Gamasiphis pulchellus (Berlese, 1887)}

Material examined. Three females and one male (NIBR). As197, Democratic People's Republic of Korea, South Pyeongannam-do, Pyongyang, steep lakeside cliff, 27.V. 1970, leg. Mahunka, S. \& Steinmann, H.

Distribution. Europe and Asia.

Notes. This species is recorded firstly in our previous paper (Kontschán et al., 2014).

Family Laelapidae

\section{Ololaelaps ussuriensis Bregetova \& Koroleva, 1964}

Material examined. One female (NIBR). As197. Democratic People's Republic of Korea, South Pyeongannamdo, Pyongyang, steep lakeside cliff, 27.V.1970, leg. Mahunka, S. \& Steinmann, H.

Distribution. Russia and Korean Peninsula.

Notes. This species is recorded firstly in our previous paper (Kontschán et al., 2014). 

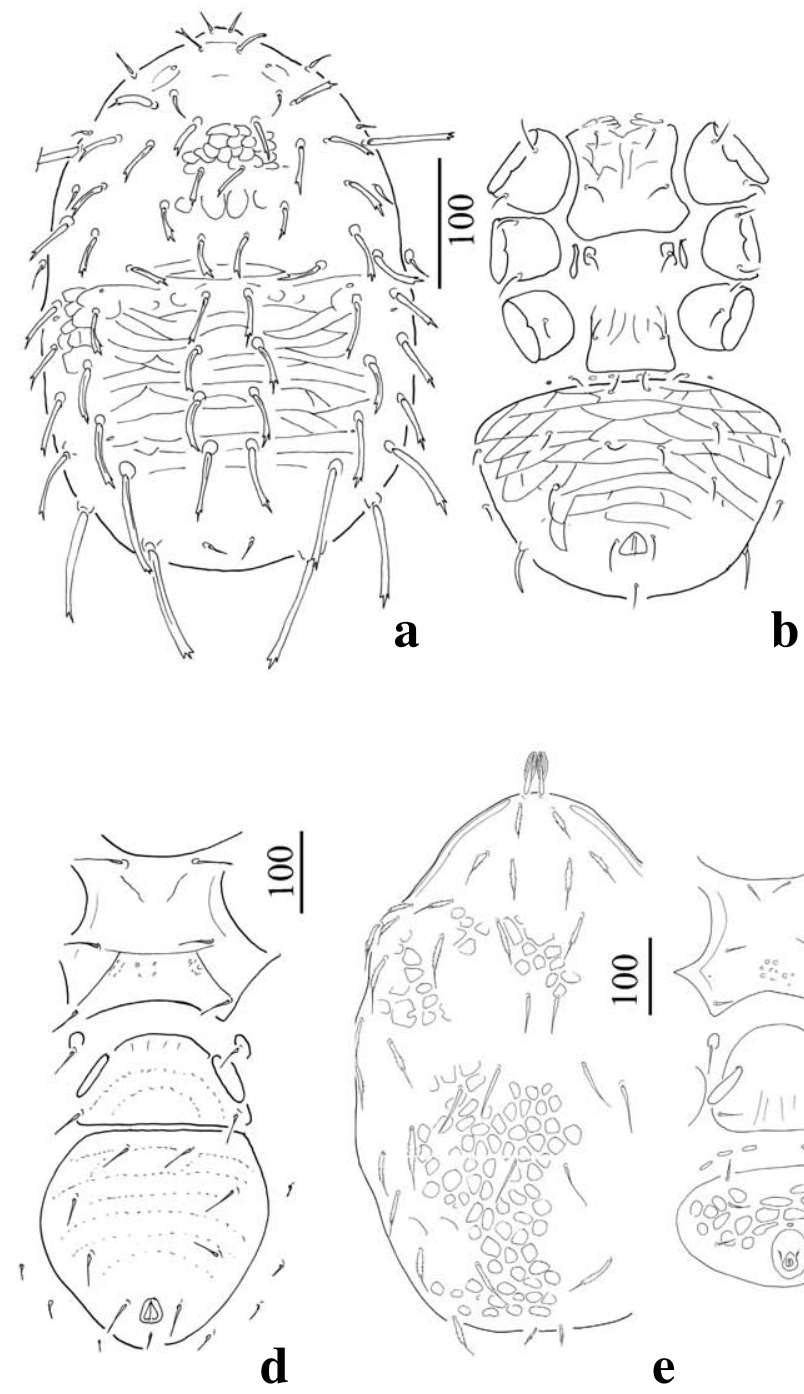

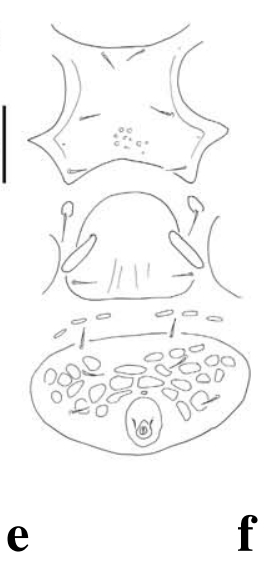

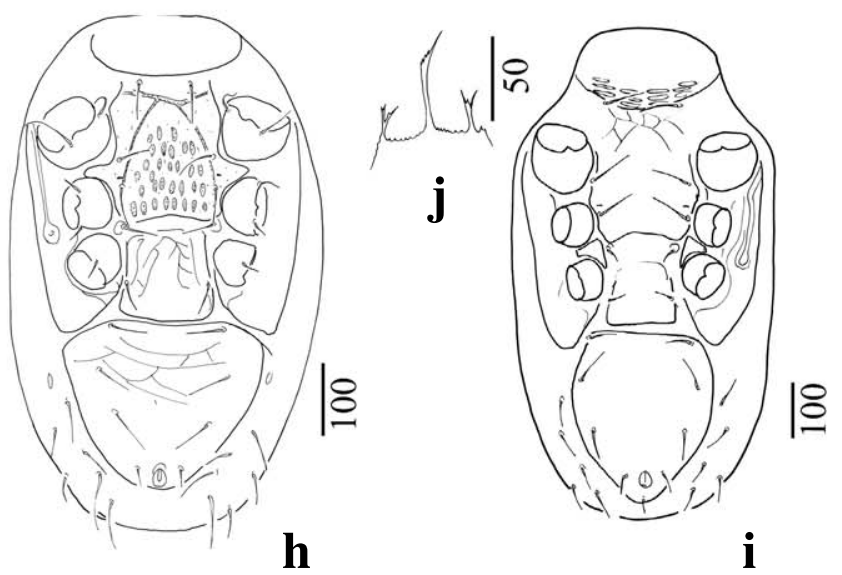

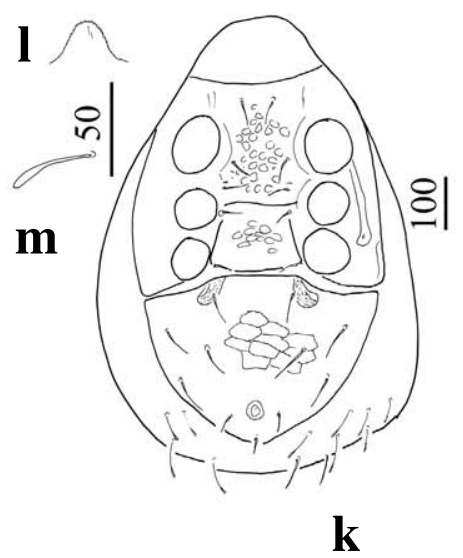

Fig. 5. Mesostigmatid mites from Korean Peninsula I. (a. Lasioseius tomokoae Ishikawa, 1969, dorsal view. b. ventral view. c. ventral view of Evimirus uropodinus (Berlese, 1903). d. ventral view of Macrocheles glaber (Müller, 1860). e. dorsal view of Macrocheles punctatus Ishikawa, 1967. f. ventral view. g. ventral view of Pachylaelaps ishizuchiensis Ishikawa, 1977. h. ventral view of Parholaspulus hiasmaticus Petrova, 1967. i. ventral view of Holaspina alstoni (Evans, 1956). j. epistome. k. ventral view of Gamasholaspis browingi (Bregetova \& Koroleva, 1960). 1. epistome. m. dorsal setae). 
Family Parholaspididae

\section{Gamasholaspis communis Petrova, 1967}

Material examined. As964, Republic of Korea, Gangwon-do, Inje-gun, Seoraksan, Misiryeonggogae, beneath the rest area, forest brook, deciduous rocky forest, open grassland and rocks, from leaf litter, $745 \mathrm{~m}, \mathrm{~N} 38^{\circ} 12.963^{\prime}$ E12826.189', 10.X.2010, leg. Murányi, D. (NIBR).

Notes. This species is recorded firstly in our previous paper (Kontschán et al., 2014).

\section{Gamasholaspis variabilis Petrova, 1967}

Material examined. One female (NIBR). As454, Democratic People's Republic of Korea, North Pyonganbukdo, Myohyangsan, sifted litter taken under Ryongyon waterfall to be extracted in Moczarsky-Winkler apparatus, 15.VII.1982, leg. Forró, L. \& Ronkay, L. (NIBR).

Notes to the species. This species is recorded firstly in our previous paper (Kontschán et al., 2014).

\section{Parholaspulus hiasmaticus Petrova, 1967 (Fig. 5h)}

Material examined. One female. As558, Democratic People's Republic of Korea, North Pyonganbuk-do, Myohyangsan, pathway Sangwon-am, sifted material from the litter of a rocky forest, to be extracted by MoczarskyWinkler-funnel, 09.X.1987, leg. Korsós, Z. \& Ronkay, L. (NIBR).

Short description. Dorsal setae long, smooth and needle like, dorsal shield covered by reticulate sculptural pattern. Sternal shield with deep and irregular pits, genital shield and ventrianal shields ornamented by reticulate pattern. Epistome with three anterior processes, central one longer than two lateral ones and apically asymmetric.

Distribution. East-Russia and Korean Peninsula.

Notes to the species. This species is recorded firstly in our previous paper (Kontschán et al., 2014).

\section{Holaspina alstoni (Evans, 1956) (Fig. 5i, j)}

Material examined. As956, Republic of Korea, Gyeongsangnam-do, Sancheong-gun, Jirisan, Ogeok valley, $3 \mathrm{~km}$ NW of Daewon temple, $\mathrm{N}$ branch of Yup-yeong, mixed forest, forest stream, open spring and its outlet, forest edge, $675 \mathrm{~m}, \mathrm{~N} 35^{\circ} 22.926^{\prime} \mathrm{E} 127^{\circ} 47.112^{\prime}, 16.09 .2010$, leg. Hye Woo Byeon, László Forró, Tae Woo Kim, Makranczy, Gy. \& Murányi D.

Short description. Dorsal setae smooth and needle like, dorsal shield without sculptural pattern. Surface of sternal, genital and ventral shields smooth, setae on ventral idiosoma smooth and needle-like. Epistome with three anterior processes, central one longer than two lateral ones and apically asymmetric and serrate, two lateral ones divided into several short branches.

Notes. This species is recorded from the Korean Peninsula by Lee and Lee (2000).

\section{Gamasholaspis browningi (Bregetova \& Koroleva, 1960) (Fig. 5k, l, m)}

Material examined. As665, One female (NIBR). As665, Democratic People's Republic of Korea, Jeju-do, Hallasan National Park, moss and soil samples (four different items) were taken from mosses, detritus, litter and upper layers of soil, 30.X.1993, leg. Peregovits, L. \& Ronkay, L.

Short description. Dorsal setae long, apically spatulate, dorsal shield covered by reticulate sculptural pattern. Sternal and genital shields with oval pits, ventrianal shield ornamented by reticulate pattern. Epistome apically rounded, its margin serrate.

Notes. This species is recorded from the Korean Peninsula by Lee and Lee (2000).

Family Podocinidae

Podocinum tsushimanum Ishikawa, 1970 (Fig. 6a, b, c)

Material examined. As452, Democratic People's Republic of Korea, North Pyeonganbuk-do, Myohyangsan, sites litter taken from mixed forest under Unsam waterfall to be extracted in Moczarsky-Winkler apparatus, 17. VII.1982, leg. Forró, L. \& Ronkay, L.

Short description. Dorsal shield covered by small rounded and triangular knobs which organized in pentagramlike web-structures. Majority of dorsal setae marginally pilose, one pair on apical area and several pairs on caudal area are very long. Epistome with three apical branches, these branches long and apically serrate.

Distribution. Japan and Korean Peninsula.

Notes to the species. This species is recorded firstly in our previous paper (Kontschán et al., 2014).

Family Ologamasidae

\section{Neoparasitus scleoides Ishikawa, 1969 (Fig. 6d, e)}

Material examined. As450, Democratic People's Republic of Korea, Pyeongyang: Yongaksan, soil sample taken from a mixed forest to be extracted in Berlese-funnel, 12. VII.1982, leg. Forró, L. \& Ronkay, L. (NIBR).

Short description. Dorsal, ventrianal and sterna shield covered by reticulate sculptural pattern. Anterior margin of sterna shield strongly sclerotized, ventrianal shield bearing four pairs of smooth and needle-like setae. Three pairs of spatuliform setae situated on membranous cuticle 

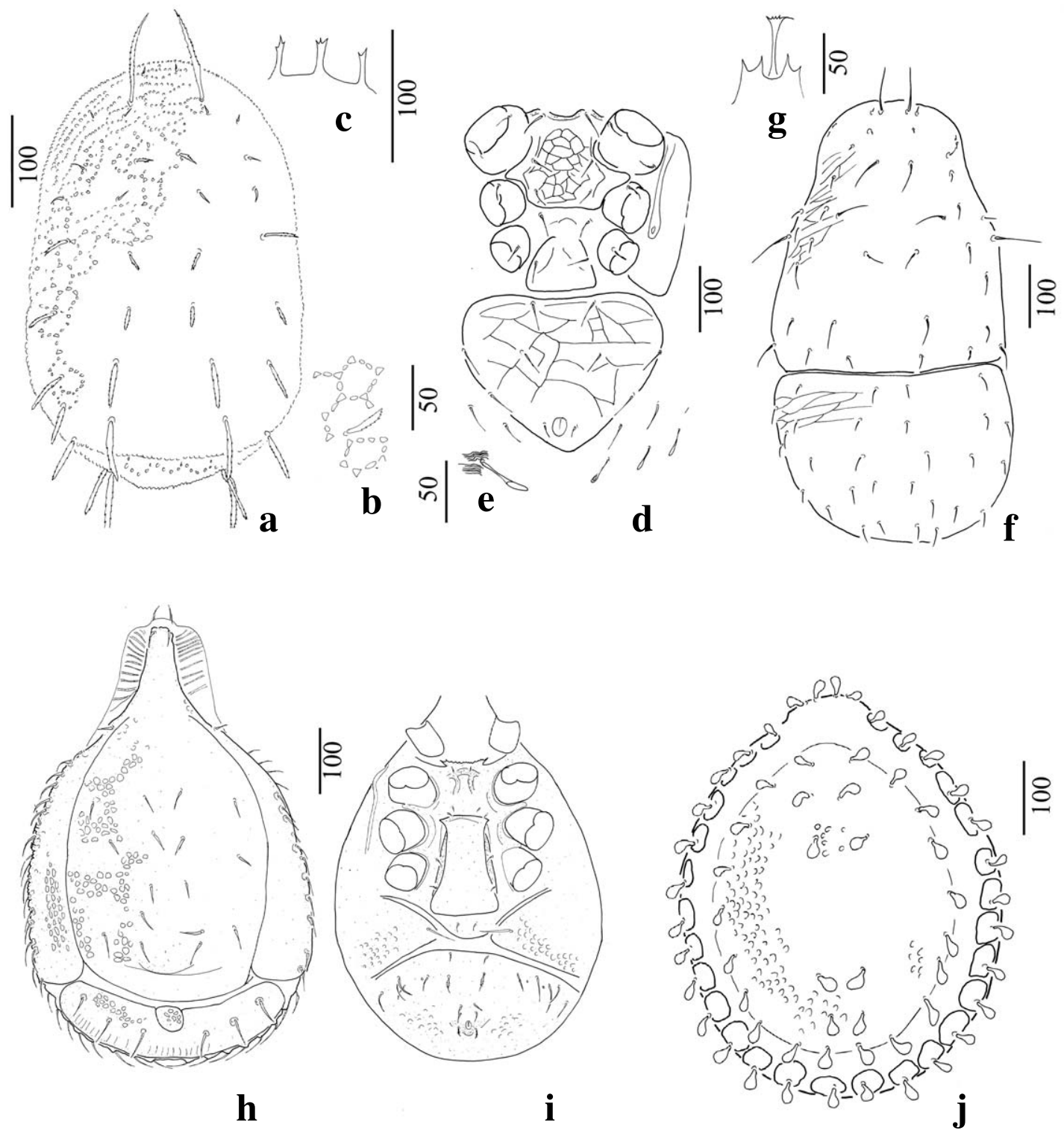

Fig. 6. Mesostigmatid mites from Korean Peninsula II. (a. ventral view of Podocinum tsushimanum Ishikawa, 1970. b. sculptural pattern. c. epistome. d. ventral view of Neoparasitus scleoides Ishikawa, 1969. e. spatuliform setae situated on membranous cuticle. f. dorsal view of Veigaia ochracea Bregetova, 1961. g. epistome. h. dorsal view of Trachytes koreana Kontschán et al., 2014. i. ventral view. j. dorsal view of Uropoda similihamulifera Hiramatsu, 1979).

near lateral margin of ventrianal shield.

Distribution. Japan and Korean Peninsula.

Notes to the species. This species is recorded firstly in our previous paper (Kontschán et al., 2014).

\section{Family Veigaiidae}

\section{Veigaia ochracea Bregetova, 1961 (Fig. 6f, g)}

Material examined. Two females (NIBR). As446, Democratic People's Republic of Korea, Pyeongyang-si: Daesongsan, $10 \mathrm{~km} \mathrm{NW}$ of Pyongyang, soil sample taken from Pinus forest near Ingo-mot pond to be extracted in Berlese-funnel, 08.VII.1982, leg. Forró, L. \& Ronkay, L. Two females (NIBR). As454, Democratic People's Republic of Korea, North Pyeonganbuk-do, Myohyangsan sifted litter taken under Ryongyon waterfall to be extracted in Moczarsky-Winkler apparatus, 15.VII.1982, leg. Forró, L. \& Ronkay, L. Four females (two in NIBR, two in HNHM). As455, Democratic People's Republic of Korea, North Pyeonganbuk-do, Myohyangsan sifted material collected in the mixed forest behind Hotel Myohyang-san to be extracted in Moczarsky-Winkler apparatus, 17.VII.1982, leg. Forró, L. \& Ronkay, L. 
Short description. Holodorsal shield completely divided into two large plates. Several setae situated on anterior area of podonotal shield are very short, numerous of setae are longer and five pairs of them are very long. Setae on opistonotal shield are uniform in shape and length. Both dorsal shield covered by fine reticulate sculptural pattern. Lateral parts of epistome with two pairs of robust spines, central process wide, asymmetric, calyx-like and apically pilose.

Distribution. East-Russia and Korean Peninsula.

Notes to the species. This species is recorded firstly in our previous paper (Kontschán et al., 2014).

\section{Family Uropodidae}

\section{Uropoda similihamulifera Hiramatsu, 1979 (Fig. 6j)}

Material examined. Two females. As224 Two females (NIBR). As224 Democratic People's Republic of Korea, Hwanghaebuk-do, Bagyeonsan, San-chon tong, about $20 \mathrm{~km}$ SE from Gyeseong, margin of stream bed, ant nest under stone, 08.VI.1970, leg. Mahunka, S. \& Steinmann, $\mathrm{H}$.

Short description. All dorsal and ventral setae apically wide and bulbiform. Dorsal shield gibbous, ornamented by oval pits. Marginal shield divided into platelets. Genital shield scutiform with oval pits on its surface.

Distribution. Japan and Korean Peninsula.

Notes to the species. This species is recorded firstly in our previous paper (Kontschán et al., 2014).

\section{Family Trachytidae}

\section{Trachytes koreana Kontschán et al., 2014 (Figs. 31-33)}

Material examined. Eight females (as type see Kontschán et al., 2014). As212, Democratic People's Republic of Korea, Gangwon-do, Geumgangsan, Man-mul san, from ant nest, 30.V.1970, leg. Mahunka, S. \& Steinmann, $\mathrm{H}$.

Short description. Wide and ribbed lateral sections on vertex present. All setae on dorsal and postdorsal shields smooth and needle-like. Surface of dorsal body covered by deep, irregular pits. Surface of sternal shield smooth, but a ח-like strongly sclerotized line situated near anterior margin of sterna shield. Sternal, ventral and inguinal shields not fused. Surface of ventral shield ornamented by oval pits. Membranous cuticle without setae. Genital shield ax-like, antarolateral angles of genital shield pointed, points directed laterally. Surface of genital shield smooth.

Notes. This species is described in Kontschán et al. (2014) from North-Korea; this was the first record of the genus Trachytes in Korean Peninsula.
Order Oribatida

Family Archoplophoridae

\section{Archoplophora rostralis (Wilmann, 1930)}

Material examined. As963, Republic of Korea, Gangwon province, Inje-gun, Seorak Mts, Misi-ryeong pass, beneath the rest area, forest brook, deciduous rocky forest, open grassland and rocks, $745 \mathrm{~m}, \mathrm{~N} 38^{\circ} 12.963^{\prime} \mathrm{E} 128^{\circ}$ $26.189^{\prime}, 10.09 .2010$, from soil, leg. Murányi, D.

Short description. Prodorsum with pointed rostrum, sensillae thick with several spines. Notogaster with eight pairs of setae, $c_{3}$ fine situated near anterior margin, $c_{1-2}$ remote from anterior margin, $e_{1-2}$ thick.

Notes. This species is recorded from the Korean Peninsula by Paik (1980).

\section{Family Camisiidae}

\section{Camisia segnis (Hermann, 1804)}

Material examined. As443, Democratic People's Republic of Korea, Kangwon Prov., Mt. Kumgang-san, near Hotel Kumgang, five soil traps, in coniferous forest with rich undergrowth, 29.IX.1979.09, leg. Steinmann, H. \& Vásárhelyi, T.

Short description. Lamellar (le) and interlamellar (in) setae long and branches, sensilla short and club-like. Notogaster longitudinal, lateral margins not parallel with each others. Posterior part with semicircular hollow, $h_{2}$ usually curved laterally.

Notes. This species is recorded from the Korean Peninsula by Paik (1980).

\section{Camisia biurus (C.L. Koch, 1839) (Figs. 7a and 8a)}

Material examined. As571, Democratic People's Republic of Korea, Ryanggang Province: NW or Samjiyon, $31 \mathrm{~km}$ on Paekdu-san road, Larix volgensis forest (not mixed with Betula pendula) with rather poor underwood, not far from the tree borderline, sifting decayed trunks of Larix volgensis, 28.VI.1988, leg. Merkl, O. \& Szél, Gy. As574 Democratic People's Republic of Korea, Geumgangsan, pine forest, soil, 11.VII.1988, leg. Merkl, O. \& Szél, Gy.

Short description. Lamellar (le) and interlamellar (in) setae long and branches, sensilla short and club-like. Notogaster longitudinal, lateral margins parallel with each others. Posterior part with trapezoidal hollow and on caudal margin one pair of convex humps situated with a distally branches seta.

Distribution. Holarctic.

Notes to the species. This is the first record of this species from Korean Peninsula. 


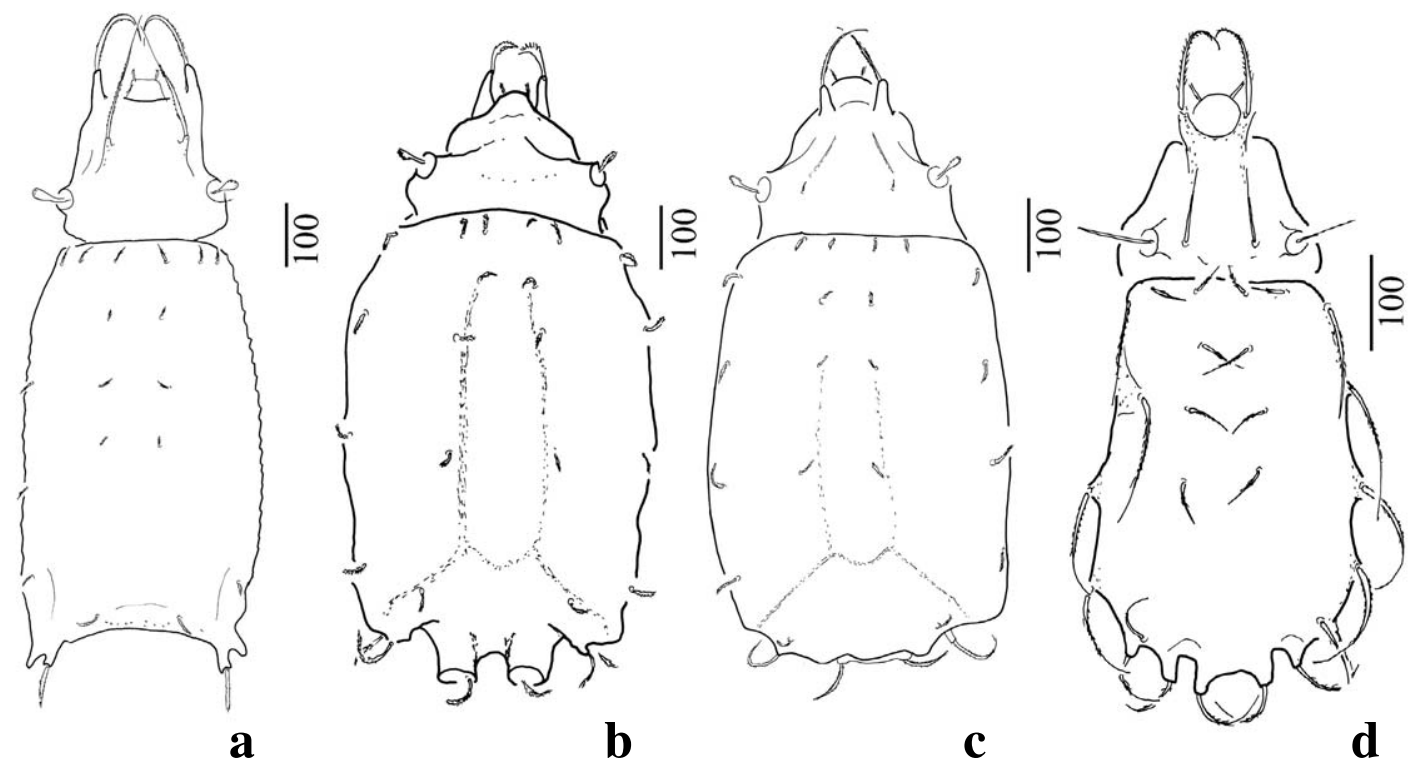

Fig. 7. Oribatid mites from the Korean Peninsula (a. dorsal view of Camisia biurus (C.L. Koch, 1839). b. dorsal view of Camisia biverrucata (C.L. Koch, 1839). c. dorsal view of Camisia horrida (Hermann, 1804). d. dorsal view of Heminothtus longisetosus Willmann, 1925).
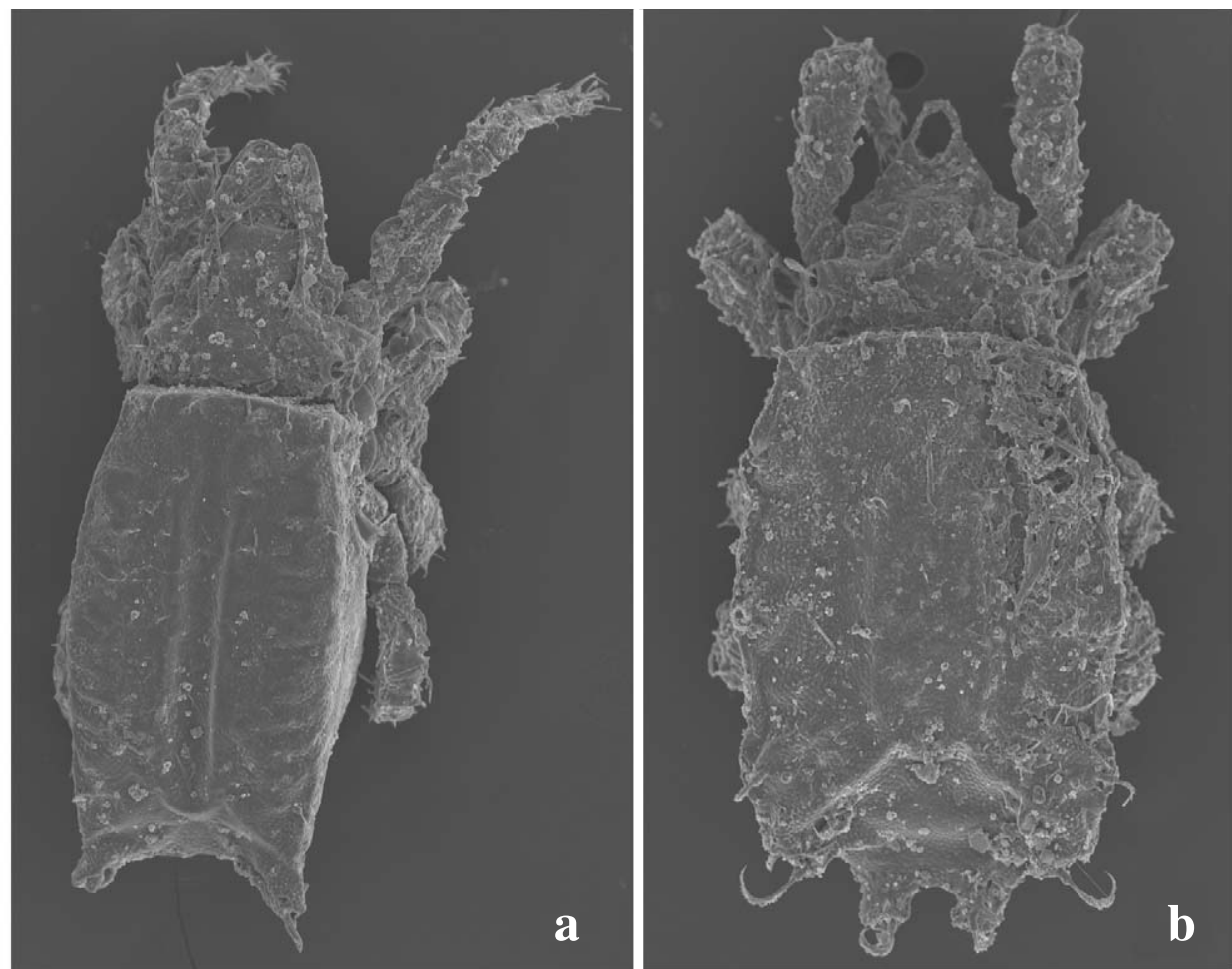

Fig. 8. Scanning micrographs about Camisiidae from Korea. a. Camisia biurus (C.L. Koch, 1839). b. Camisia biverrucata (C.L. Koch, 1839).

\section{Camisia spinifer (C.L. Koch, 1836) (Fig. 9c)}

Material examined. As571, Democratic People's Repu- blic of Korea, Ryanggang Province: NW or Samjiyon, $31 \mathrm{~km}$ on Paekdu-san road, Larix volgensis forest (not mixed with Betula pendula) with rather poor underwood, 


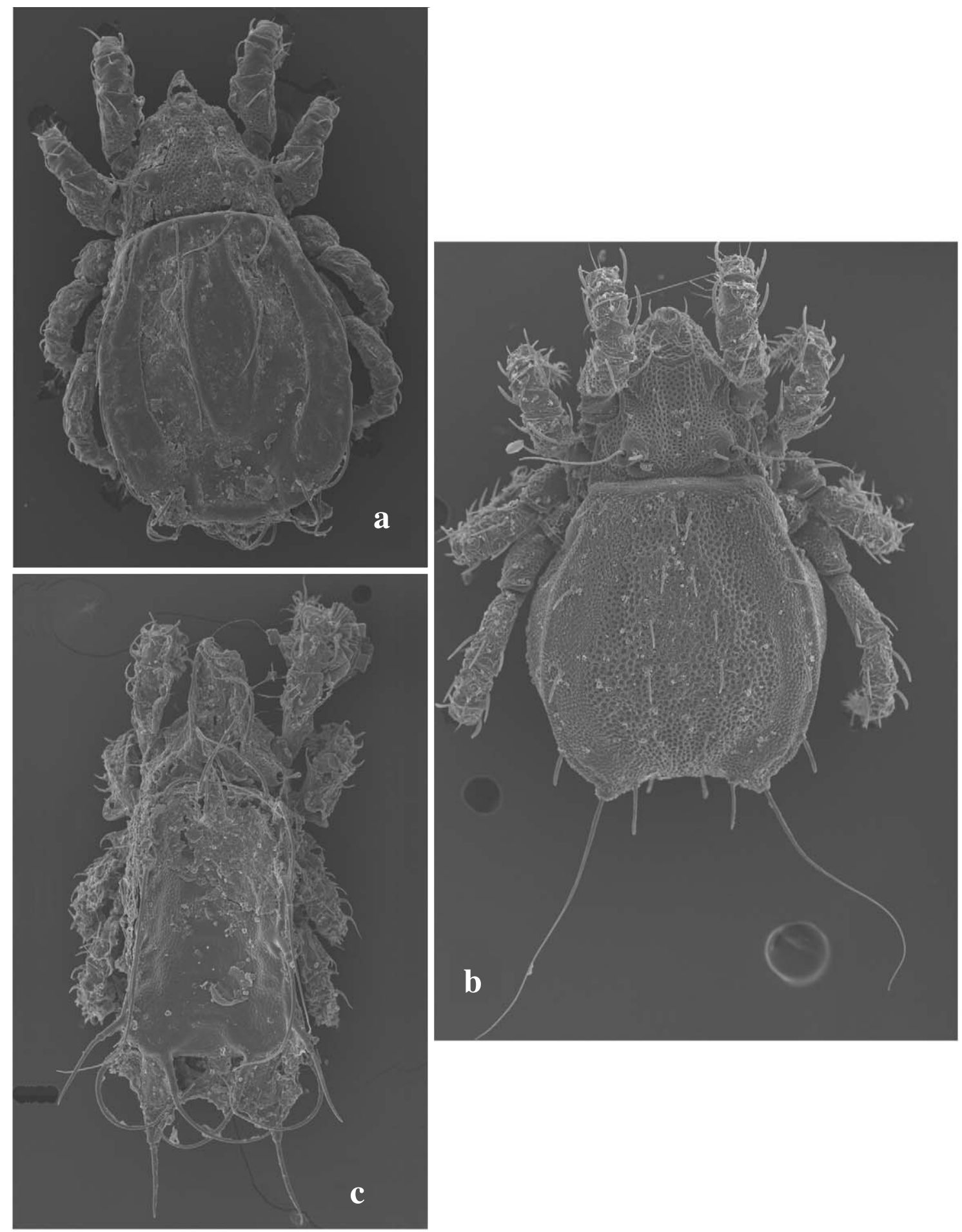

Fig. 9. Scanning micrographs about Camisiidae and Nothriidae from Korea. a. Heminothtus peltifer (C.L. Koch, 1839). b. Nothrus palustris C.L. Koch, 1839. c. Camisia spinifer (C.L. Koch, 1836).

not far from the tree borderline, sifting decayed trunks of Larix volgensis, 28.VI.1988, leg. Merkl, O. \& Szél, Gy. As574 Democratic People's Republic of Korea, Geumgangsan, pine forest, soil, 11.VII.1988, leg. Merkl,
O. \& Szél, Gy. As961, Republic of Korea, Gyeonggi province, Gapyeong-gun, Hwaak Mts, Hwaak pass, $2.5 \mathrm{~km}$ $\mathrm{S}$ of the tunnel, pine forest, $430 \mathrm{~m}, \mathrm{~N} 37^{\circ} 58.465^{\prime} \mathrm{E} 127^{\circ}$ 31.559', 11.09.2010, leg. Forró, L., Makranczy, Gy., 
Murányi D.Sun Jae Park \& Jung Do Yoon.

Short description. Tip of rostrum pointed. Lamellar (le) setae very long and branches, sensilla short and club-like. Setae $d_{1} d_{2}$ short, other setae very long and flagelliform, situated on narrow protuberances. Caudal margin with two long and wide protuberances.

Notes. This species is recorded from the Korean Peninsula by Paik (1980).

\section{Camisia biverrucata (C.L. Koch, 1839) (Figs. 7b and 8b)}

Material examined. As571, Democratic People's Republic of Korea, Ryanggang Province: NW or Samjiyon, $31 \mathrm{~km}$ on Paekdu-san road, Larix volgensis forest (not mixed with Betula pendula) with rather poor underwood, not far from the tree borderline, sifting decayed trunks of Larix volgensis, 28.VI.1988, leg. Merkl, O. \& Szél, Gy.

Short description. Lamellar setae long and situated on a prolognation. Interlamellar setae very short, due to the camouflage they can visible hardly, sensilla short and clavate. Notogaster rectangular, $c_{2}$ situated near $c_{1}$, caudal margin with two wide cylinder-shaped protuberances with one pilose setae.

Distribution. Holarctic.

Notes to the species. This is the first record of this species from Korean Peninsula.

\section{Camisia horrida (Hermann, 1804) (Fig. 7c)}

Material examined. As571, Democratic People's Republic of Korea, Ryanggang Province: NW or Samjiyon, $31 \mathrm{~km}$ on Paekdu-san road, Larix volgensis forest (not mixed with Betula pendula) with rather poor underwood, not far from the tree borderline, sifting decayed trunks of Larix volgensis, 28. VI.1988, leg. Merkl, O. \& Szél, Gy.

Short description. Lamellar setae long and situated on a prolongation. Interlamellar setae very short, due to the camouflage they can visible hardly, sensili short and clavate. Notogaster rectangular, $c_{2}$ situated near $c_{1}$, trapezoidal hollow on caudal area present.

Distribution. Holarctic.

Notes to the species. This is the first record of this species from Korean Peninsula.

\section{Heminothtus peltifer (C.L. Koch, 1839) (Fig. 9a)}

Material examined. As209, Democratic People's Republic of Korea, Prov. Kanwon: Kum-gang san, Sam-il,out above lakeshore, litter of oak woods, 29.V.1970. leg. Mahunka, S. \& Steinmann, H. As571, Democratic People's Republic of Korea, Ryanggang Province: NW or Samjiyon, $31 \mathrm{~km}$ on Paekdu-san road, Larix volgensis forest (not mixed with Betula pendula) with rather poor underwood, not far from the tree borderline, sifting decayed trunks of Larix volgensis, 28.VI.1988, leg. Merk1, O. \& Szél, Gy. As574 Democratic People's Republic of Korea, Geumgangsan, pine orest, soil, 11.VII.1988, leg. Merkl, O. \& Szél, Gy.

Short description. Tip of rostrum rounded. Lamellar and interlamellar setae short, sensilla longer than lamellar setae. Setae on margins of notogaster short and smooth not situated on apophyses, except $p_{1}, h_{1}$ and $h_{2}$ which situated on small apophyses.

Notes. This species is recorded from the Korean Peninsula by Paik (1980).

\section{Heminothtus longisetosus Willmann, 1925 (Fig. 7d)}

Material examined. As209, Democratic People's Republic of Korea, Prov. Kanwon: Kum-gang san, Sam-il above lakeshore, litter of oak woods, 29.V.1970. leg. Mahunka, S. \& Steinmann, H.

Short description. Lamellar and interlamellar setae long, setae le branches, setae in smooth, sensilla long. Setae on margins of notogaster long and pilose and situated on small apophyses, other setae smooth and situated on normal surface of notogaster.

Distribution. Holarctic.

Notes. This species was mentioned in Choi (1997) paper.

Family Nothridae

\section{Nothrus biciliatus Koch, 1841}

Material examined. As443, Democratic People's Republic of Korea, Kangwon Prov., Mt. Kumgang-san, near Hotel Kumgang, five soil traps, in coniferous forest with rich undergrowth, 29.IX.1979.09, leg. Steinmann, H. \& Vásárhelyi, T.

Short description. Lamellar and interlamellar setae short, spatuliform, sensilla long and ciliate. All setae of notogaster short and spatuliform, setae on caudal margin of notogaster spatuliform, but longer than other dorsal setae.

Notes. This species is recorded from the Korean Peninsula by Paik (1980).

\section{Nothrus silvestris Nicolet, 1855}

Material examined. As571, Democratic People's Republic of Korea, Ryanggang Province: NW or Samjiyon, $31 \mathrm{~km}$ on Paekdu-san road, Larix volgensis forest (not mixed with Betula pendula) with rather poor underwood, not far from the tree borderline, sifting decayed trunks of Larix volgensis, 28.VI.1988, leg. Merkl, O. \& Szél, Gy. Short description. Lamellar and interlamellar setae short, sensilla long and needle-like. Setae on margins of noto- 

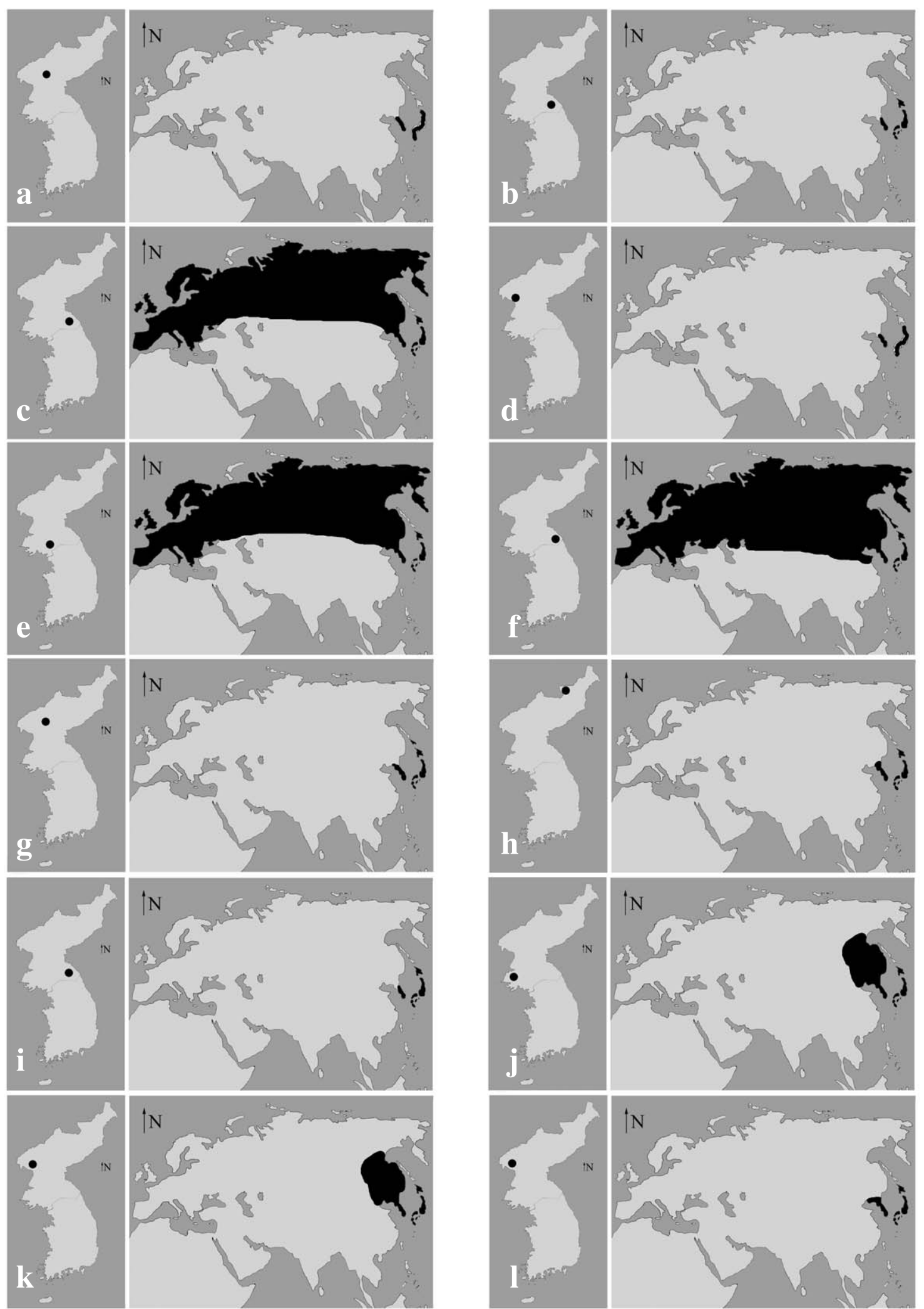

Fig. 10. Occurrences of the found mites in Korean Peninsula and distribution in the Palearctic region I. (a. Favognathus maritimus. b. Asca nubs. c. Asca aphidioides. d. Lasioseius tomokoae. e. Evimirus uropodinus. f. Macrocheles glaber. g. Macrocheles punctatus. h. Pachylaelaps ishizuchiensis. i. Gamasellus humosus. j. Gamasiphis pulchellus and Ololaelaps ussirinensis. k. Parholaspulus hiasmaticus. 1. Podocinum tsushimanum). 

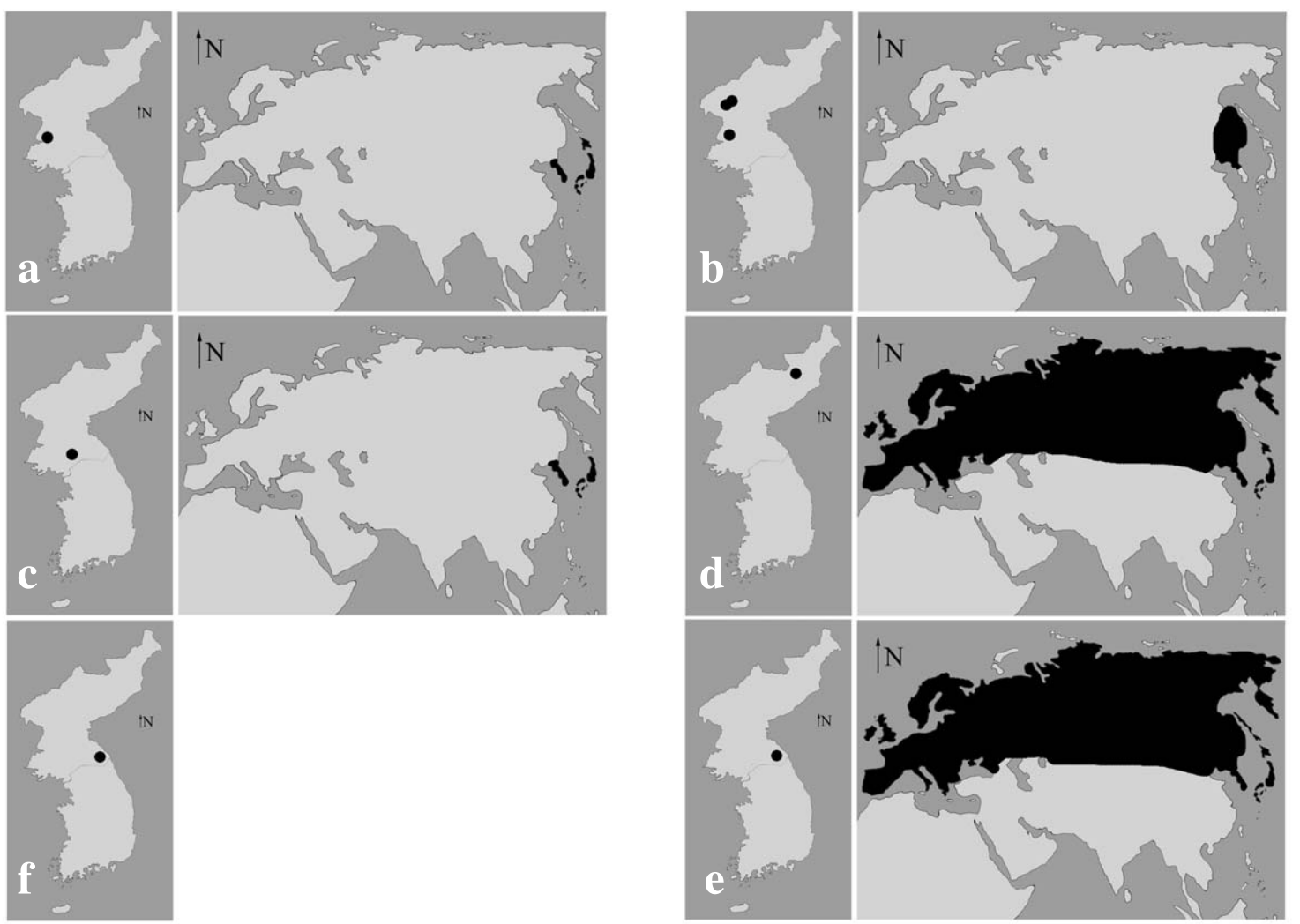

Fig. 11. Occurrences of the found mites in Korean Peninsula and distribution in the Palearctic region II. (a. Neoparasitus scleoides. b. Veigaia ochracea. c. Uropoda similihamulifera. d. Camisia biurus, Camisia biverrucata and Camisia horrid. e. Heminothtus longisetosus. f. Trachytes koreana).

gaster short, weak, but a little spatuliform setae on caudal margin similar in shape to other setae on notogaster, but longer, and usually curved medially.

Notes. This species is recorded from the Korean Peninsula by Paik (1980).

\section{Nothrus palustris C.L. Koch, 1839 (Fig. 9b)}

Material examined. As957, Republic of Korea, Jeollabuk province, Muju-gun, Deokyu Mts, Baekryeon temple, towards Osujagul cave, Gucheondong stream, surrounding deciduous forest and its sidebrook, $985 \mathrm{~m}, \mathrm{~N} 35^{\circ}$ 51.069' E127 46.169', 14.09.2010, leg. Hye Woo Byeon, Tae Woo Kim, György Makranczy, Gy. \& Murányi D.

Short description. Lamellar and interlamellar setae short, sensilla long and needle-like. Setae on notogaster short and rod-like, one pair of seta $\left(h_{2}\right)$ on caudal margin needlelike and very long.

Notes. This species is recorded from the Korean Peninsula by Paik (1980).

\section{Short zoogeographical notes}

Our new contribution to the knowledge contains 26 species from the Korean Peninsula, 23 species are recorded from Democratic People's Republic of Korea and only four species from Republic of Korea. Unfortunately the number of the samples housed in the Hungarian Natural History Museum from Republic of Korea is lower than the number of samples from Democratic People's Republic of Korea. One species seems to be endemic, the herein presented Trachytes koreana, which was found in area of Democratic People's Republic of Korea. The other species are known from several countries of Asia. Seven species from the found 26 occur in Japan as well, the other species can be found in the continental part of East Asia or in the Palearctic region.

\section{ACKNOWLedGements}

This work was supported by a grant from the National Institute of Biological Resources (NIBR), funded by the Ministry of Environment (MOE) of the Republic of Korea (NIBR No. 2013-02-054). I am grateful to our colleagues, who collected the mite samples. 


\section{REFERENCES}

Blaszak, C. 1976a. Xenozercon glaber gen. nov., sp. nov. (Acari, Zerconidae) from Democratic People's Republic of Korea. Bulletin of Academy of Polish Sciences 24(1): 33-36.

Blaszak, C. 1976b. Systematic studies on family Zerconidae II. Democratic People's Republic of Korea n Zerconidae (Acari, Mesostigmata). Acta Zoologica Cracoviensia 21(16):527-552.

Choi, S.S. 1997. Checklist of Oribatid Mites (acari: Oribatida) of Korea. Korean Arachnology 13(1):83-104.

Doğan, S. 2008. A catalogue of cryptognathid mites (Acari: Prostigmata, Cryptognathidae) with the descriptions of a new species of Favognathus Luxton and a newly discovered male of F. amygdalus Doğan and Ayyildiz from Turkey. Journal of Natural History 42(23-24):1665-1686.

Kontschán, J., S.J. Park, T.J. Yoon and W.Y. Choi. 2012. New Uropodina records and species from the Korean Peninsula (Acari: Mesostigmata). Opuscula zoologica Budapest 43:169-177.

Kontschán, J., S.J. Park, T.J. Yoon and W.Y. Choi. 2013. Uropodina mites from Korean Peninsula (Acari: Mesostigmata). AdLibrum Kiadó, Budapest.

Kontschán, J., S.J. Park, J.W. Lim, J.M. Hwang and H.J. Seo.
2014. New Mesostigmata records and species from the Korean Peninsula. Opuscula Zoologica Budapest (in press).

Lee, S.Y. 1994. A taxonomic studies on genus Asca (Ascidae: Mesostigmata) in Korea. Master Thesis.

Lee, W.K. and S.Y. Lee. 2000. Taxonomic Study of Parholaspid Mites (acari: Mesostigmata) in Korea. The Korean Journal of Systematic Zoology 16(1):105-112.

Mahunka, S. 1971. Tarsonemina (Acari) species from Korea. Zoological Collectings of the Hungarian Natural History Museum in Korea (Nr.3.). Acta Zoologica Academiae Scientiarum Hungaricae 17(3-4):271-294.

Mahunka, S. 1973. Zwei neue Lohmanniiden-Arten aus Korea (Acari, Oribatida). Folia Entomologica Hungarica 26(1): 49-56.

Mahunka, S. 1980. Parapygmephorus delyorum sp.n., eine neue Art aus Korea (Acari: Tarsonemina). Parasitologica Hungarica 13:95-98.

Mahunka, S. 1982. Ptychoide Oribatiden aus der Koreanischen Volksdemokratischen Republik (Acari). Acta Zoologica Academiae Scientiarum Hungaricae 28(1-2):83-103.

Paik, H.W. 1980. Tentative catalogue of Oribatid mites (Acari: Cryptostigmata) of Korea. Korean Journal of Plant Protection 19(4):251-257.

Submitted: January 7, 2014, Accepted: February 6, 2014 